\title{
Pengetahuan Keuangan dan Love Of Money pengaruhnya terhadap Pengelolaan Keuangan Pribadi dan dampaknya terhadap Kesejahteraan Masyarakat Desa Cihambulu, Kec. Pabuaran Kab. Subang
}

\author{
Rudy $^{1)}$; Nardi Sunardi ${ }^{2}$; Kartono $^{3)}$ \\ ${ }^{1,2,3)}$ dosen Universitas Pamulang, email :dosen00802@unpam.ac.id
}

ABSTRACT

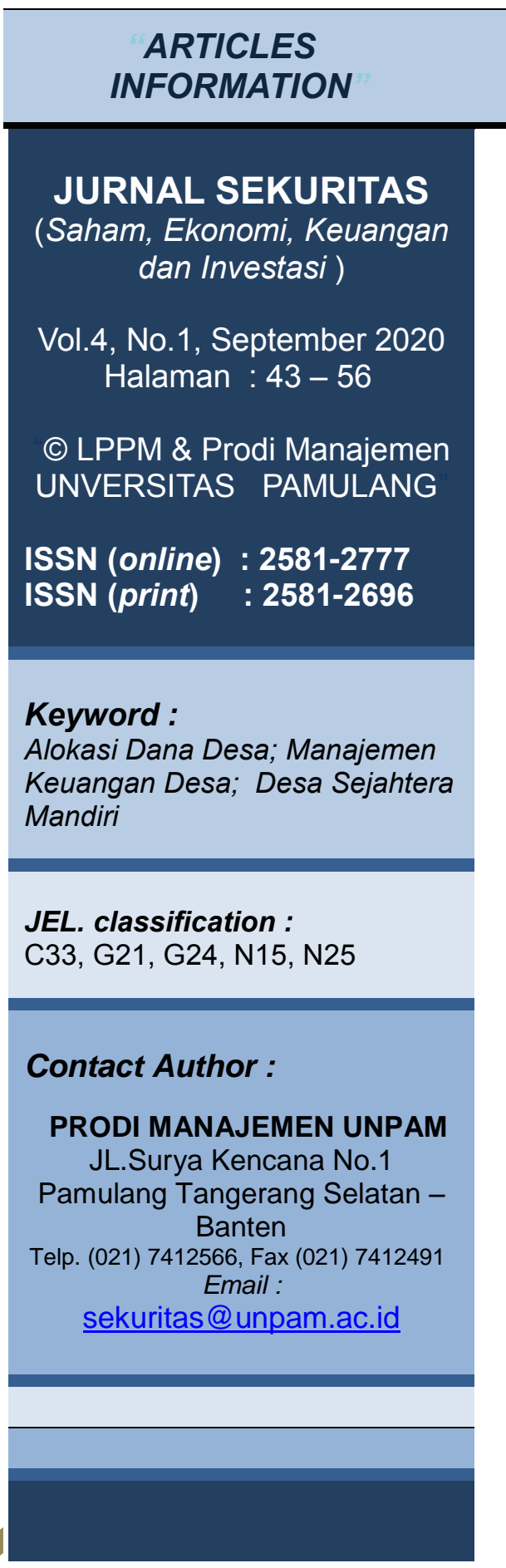

\section{JURNAL SEKURITAS}

(Saham, Ekonomi, Keuangan dan Investasi )

Vol.4, No.1, September 2020 Halaman : $43-56$

@) LPPM \& Prodi Manajemen UNVERSITAS PAMULANG

\section{ISSN (online) : 2581-2777 ISSN (print) : 2581-2696}

Keyword :

Alokasi Dana Desa; Manajemen Keuangan Desa; Desa Sejahtera Mandiri

JEL. classification :

C33, G21, G24, N15, N25

\section{Contact Author}

RODI MANAJEMEN UNPAM

L.Surya Kencana No.

Tangerang Selatan -

Telp. (021) 7412566, Fax (021) 741249 Email :

sekuritas@unpam.ac.id

Jurnal SEKURITAS(Saham, Ekonomi, Keuangan dan Investasi ) , Vol.4, No.1, September 2020... 43
Penelitian ini bertujuan untuk mengetahui bagaimana pengaruh pengetahuan keuangan, love of Money terhadap pengelolaan keuangan pribadi dan dampaknya terhadap Kesejahteran Mayarakat Desa Cihambulu Kecamatan Pabuaran Kabupaten Subang Jawa Barat.

Dengan metode confirmatory analys factor menggunakan uji regression weight melalui perangkat Amos SPSS 23 . Responden adalah warga desa Cihambulu sebanyak 100 orang. Hasil penelitian menunjukkan pengetahuan Keuangan Pribadi (PKP) tidak berpengaruh secara signifikan terhadap Pengelolaan Keuangan Pribadi (PKPI) dengan nilai Critical Rasio $0.016<1,196$. Love Of Money (LOM) tidak berpengaruh secara signifikan terhadap Pengelolaan Keuangan Pribadi (PKPI) dimana Critical Rasio $1,914<1,96$. Pengetahuan Keuangan Pribadi (PKP) tidak berpengaruh secara signifikan terhadap Kesejahteraan Masyarakat Desa dimana Critical Rasio $-0,769<1,96$. Love Of Money (LOM) tidak berpengaruh secara signifikan terhadap Kesejahteraan Masyaraat Desa (KM) dimana Critical Rasio $0,596<1,96$. Pengelolaan Keuangan Pribadi Berpengaruh secara signifikan Terhadap Kesejahteraan Masyarakat Desa dimana Critical Rasio 7,516 > 1,96

This study aims to determine how the influence of financial knowledge, love of money on personal financial management and its impact on the welfare of the people of Cihambulu Village, Pabuaran District, Subang Regency, West Java.

The confirmatory analys factor method uses the regression weight test through the Amos SPSS 23 device. Respondents were 100 Cihambulu villagers. The results showed the knowledge of Personal Finance did not significantly influence Personal Financial Management with a Critical Ratio value of $0.016<1.196$. Love of Money does not significantly influence Personal Financial Management where the Critical Ratio of $1.914<1.96$. Personal Financial Knowledge does not significantly influence the welfare of the Village Community where the Critical Ratio of $-0.769<1.96$. Love of Money does not significantly influence the welfare of the Village Community (KM) where the Critical Ratio is $0.596<1.96$. Personal Financial Management Significantly Influences Village Community Welfare, where a Critical Ratio of 7.516> 1.96. 


\section{A. PENDAHULUAN}

Setiap manusia mengharapkan hartanya dapat menjadi berkah baginya dengan mengikuti aturan dan ketentuan serta pengaturan yang terbaik. Untuk itu, diperlukan suatu perencanaan atau pengelolaan keuangan yang sesuai dengan pola hidup manusia itu sendiri yang umum dikenal perencanaan dan pengelolaan keuangan pribadi. Perencanaan dan pengelolaan keuangan adalah proses pengambilan keputusan untuk mencapai suatu tujuan yang di kehendaki (mencari dan mengonsumsi harta). Dengan manajemen keuanngan (perencanaan, penganggaran, pemeriksaan, pengelolaan, serta pengendalian) dengan tidak bertentangan dengan aturan dan hukum, baik hukum agama ( syar'i) maupun hukum negara. Pengelolaan keuangan yang sesuai dengan aturan bertujuan mendatangkan kemaslahatan, baik di dunia maupun di akhirat

Manajemen keuangan pribadi merupakan seni dan ilmu mengelola sumber daya (money) dari unit individual atau rumah tangga (Gitman 2002). Dalam proses pengelolaan tersebut, maka tidak mudah untuk mengaplikasikannya karena terdapat beberapa langkah sistematis yang harus diikuti. Namun dengan mengetahui manajemen keuangan pribadi, merupakan langkah awal untuk aplikasi yang tepat ketika mengelola uang pribadi. Hal ini didasari alasan bahwa segala sesuatu diawali dari kepala. Maksudnya adalah berpikir dahulu baru bertindak. Berpijak pada ulasan di atas maka pengelolaan keuangan pribadi juga menunut adanya pola hidup yang memiliki prioritas. Kekuatan dari prioritas (the power of priority) berpengaruh juga pada tingkat kedisiplinan seseorang ketika mengelola uangnnya (Benson 2004 dalam Magfirah 2017). Kedisiplinan yang merupakan kesadaran diri untuk mematuhi aturan serta kemampuan diri untuk menyesuaikan dirinya dengan perubahan, maka secara eksplisit telah menyentuh kontrol diri (self control). Hal ini berpijak pada alasan bahwa sukses atau tidaknya seseorang dalam mengelola keuangannya juga salah satunya turut dipengaruhi oleh kontrol diri (Tangney 2004 dalam Magfirah 2017) .

Pembahasan kepribadian dalam mengelola uang sebenarnya menggambarkan hubungan emosional dari pelaku keuangan dengan kondisi masa lalu atau pun ciri khasnya. Dalam arti bahwa hubungan emosional terhadap uang tersebut dapat memicu berbagai masalah keuangan seperti salah satunya adalah pemborosan, terjebak utang, dan lainlain. Hal ini membuka peluang untuk mengetahui mengapa, aspek emosional yang mendorong terciptanya perilaku keuangan seseorang dapat menjadi nilai-nilai yang diyakininya terkait mengelola uang seperti uang adalah nilai diri, uang adalah keamanan, uang adalah cinta, uang adalah penenang, uang adalah gengsi, uang adalah kekuasaan, dan yang terakhir yaitu uang adalah kebahagiaan (Sina, 2014 dalam Magfirah 2017), hubungan emosional pada masa lalu dari pelaku keuangan yang mana dijadikan pertimbangan logis untuk membuat berbagai tipe kepribadian. Selanjutnya, karena adanya hubungan emosional yang relatif menjadi hambatan seseorang dalam mengelola keuangan maka meningkatkan berbagai masalah keuangan yang dapat menyebabkan terjadinya kebangkrutan personal. Namun seperti yang diketahui bahwa, pendekatan kepribadian tidak saja digunakan untuk membedah bagaimana seseorang mengelola uangnya melainkan juga dijadikan sebagai upaya kreatif dalam membuat terapi keuangan yang logis, tepat sasaran dan dapat dikonsumsi oleh publik (Goodman, 2007) .

Howell 1993 dalam Magfirah 2017, menyatakan bahwa pengelolaan keuangan pribadi merupakan salah satu kompetensi yang paling dasar yang dibutuhkan oleh masyarakat modern, karena pilihan konsumen dari hari ke hari akan mempengaruhi keamanan keuangan dan standar hidup seseorang. Meskipun demikian, Harder (2001) menunjukkan bahwa topik keuangan pribadi sering diremehkan dalam pendidikan saat ini. Kebanyakan orang cenderung untuk belajar mengenai keuangan pribadi melalui proses trial dan eror. Mengatasi kekurangan keuangan pribadi tidak hanya dapat mencegah potensi 
fiskal, tetapi juga mengajarkan cara yang tepat bagaimana untuk mengelola uang yang juga akan menjadikannya sebagai implikasi perkembangan positif .

Setiap individu disarankan untuk dapat mengelola keuangannya sendiri. Ada beberapa alasan mengapa setiap individu memerlukan pengelolaan keuangan (Senduk, 2001) yaitu Adanya tujuan keuangan yang ingin dicapai, naiknya biaya hidup dari tahun ke tahun, keadaan perekonomian tidak akan selalu baik, tingginya biaya hidup saat ini, fisik manusia tidak akan selalu sehat. Lebih lanjut, (Senduk, 2001) mengemukakan tentang komponen awal dalam mengelola keuangan pribadi adalah perencanaan keuangan yang diartikan sebagai proses merencanakan tujuan-tujuan keuangan jangka pendek maupun jangka Panjang .

Individu membutuhkan pengetahuan keuangan dasar serta skill untuk mengelola sumber daya keuangan secara efektif demi kesejahteraan hidupnya. Kebutuhan individu dan produk financial yang semakin kompleks menuntut masyarakat untuk memiliki financial literacy yang memadai. Penguasaan ilmu dan skill di bidang keuangan mendorong individu untuk memahami dan terlibat dalam nasional di bidang keuangan. Dalam hal ini seperti yang dikemukakan dalam social learning theory dimana perilaku seseorang tidak hanya dipengaruhi dari dalam diri seseorang tapi ada impuls dari luar yang menyebabkan perubahan perilaku dari seseorang. Dengan teori belajar secara tradisional menyatakan bahwa belajar terjadi dengan cara menunjukkan tanggapan (respon) dengan apa yang telah diperhatiakan (Bandura. 1977). Teori ini mengandung banyak implikasi dalam pengelolaan keuangan baik pengelolaan pribadi maupun keluarga karena dengan belajar dari pengalaman sendiri maupun pengalaman tidak langsung lewat pengamatan dapat meningkatkan pengetahuan seseorang dalam mengelola keuangan pribadinya .

Pengembangan teori yang mendukung teori diatas yaitu teori kognitif social theory yang menjelakan bahwa kemampuan manusia untuk belajar adalah bisa mempresentasikan kejadian, menganalisa pengalaman sadarnya, berkomunikasi dengan orang lain, merencanakan menciptakan, membayangkan, dan melakukan tindakan dengan perhitungan. Dalam hal ini dijelaskan juga bahwa belajar secara langsung atau tidak langsung biasanya melibatkan orang lain dalam setting social. Dalam kondisi seperti ini seseorang mengelola keuangannya dapat mengikuti perilaku seseorang dengan cara mendapatkan pengembalian (income) yang lebih besar dari pada apa yang sudah dikeluarkan bukan hanya itu dengan belajar dari lingkungan sekitarnya seseorang dalam mengelola keuangan kebanyakan yang meniru sesuatu yang ada dilingkungannya .

Pemahaman akan kecintaan seseorang terhadap uang dianggap penting karena kecintaan akan uang dapat menumbuhkan perilaku yang positif maupun yang negatif (Furnham, 2013), misalnya menunjukkan bahwa kecintaan seseoran akan uang yang tinggi akan mengakibatkan seseorang menjadi tamak dan kurang dapat bekerja dengan baik dengan rekan-rekan mereka. Disisi lain kecintaan seseorang akan uang (the love of money) sering dinotasikan secara negatif karena banyak orang menganggap uang di atas segalanya dan dianggap tabu di kalangan masyarakat tertentu. Pemahaman kecintaan akan uang dikalangan masyarakat dianggap memiliki peranan penting dalam lalu lintas perekonomian dan pergaulan masyarakat dalam suatu negara. Di sisi lain, hasil penelitian Istijanto (2015) mengidentifikasi bahwa keberhasilan negara China dalam pertumbuhan ekonomi terkait dengan sikap masyarakat mereka yang tidak bisa lepas dari uang artinya dalam kehidupan yang lebih makro, sikap masyarakat yang sangat positif terhadap uang dan memanajemen keuangan mereka dengan baik mampu memberikan kontribusi dalam keberhasilan ekonomi di negara tersebut .

Berdasarkan uraian tersebut, penulis tertarik untuk mengadakan penelitian dengan judul "Pengetahuan Keuangan dan Love Of Money pengaruhnya terhadap Pengelolaan Keuangan Pribadi dan dampaknya terhadap Kesejahteraan Masyarakat Desa Cihambulu, Kec. Pabuaran Kab. Subang". 


\section{B. KAJIAN LITERATUR}

\section{Manajemen Keuangan Pribadi}

Menurut Gitman dalam Maghfiroh (2017) bahwa manajemen keuangan merupakan proses perencanaan, analisa dan pengendalian kegiatan keuangan. Salah satu bentuk aplikasi dari manajemen keuangan adalah yang disebut manajemen keuangan pribadi yaitu proses perencanaan dan pengendalian keuangan dari unit individu atau keluarga. Sumber lain, Guhardja (1992) dalam Surachman, Sukmaningtyas, dan Mutiarani (2010) menyatakan bahwa pemilikan sumberdaya uang dalam suatu keluarga akan relatif terbatas, tergantung kepada jumlah dan kualitas orang yang berpartisipasi dalam pencarian pendapatan, sedangkan keinginan dan kebutuhan setiap keluarga dan anggota relatif tidak terbatas. Bahkan keinginan dan kebutuhan akan barang atau jasa dari setiap keluarga dan anggotanya dari waktu ke waktu selalu berubah dan cenderung bertambah banyak .

Manajemen Keuangan pribadi yaitu suatu seni mengelola uang baik perorangan maupun kelompok (rumah tangga) untuk menapai tujuan yang telah di rencanakan sebelumnya, dalam prosesnya pengelolaannya tidak mudah untuk mengaplikasikannya, dengan menerapkan manajemen keuangan pribadi pengeluaran dan pemasukan kebutuhan terkontrol dari perancanaann sampai evaluasi pengeluaran maupun pemasukan. Dengan demikian, agar pemanfatan sumber daya uang yang terbatas tersebut mencapai optimum diperlukan usaha manajemen keuangan yang baik dan efektif. Walaupun manajemen tidak dapat membuat sumberdaya yang tidak cukup untuk memenuhi kebutuhan dan keinginan menjadi cukup, akan tetapi manajemen dapat membantu menetapkan penggunaan sumberdaya yang terbatas untuk item yang disetujui oleh semua anggota keluarga .

Senduk (2004) memperkuat dengan menyatakan bahwa manajemen keuangan pribadi meliputi keputusan tentang: Pertama, membeli dan memiliki sebanyak mungkin harta produktif. Maksudnya adalah caranya dengan tentukan harta produktif yang ingin dimiliki, tulis pos-pos harta produktif yang anda inginkan tersebut di kolom harta produktif, segera setelah mendapatkan gaji, prioritaskan untuk memiliki pos-pos harta produktif sebelum membayar pengeluaran yang lain. kalau perlu, pelajari seluk-beluk masing-masing harta produktif tersebut. Kedua, atur pengeluaran anda. Nalarnya adalah caranya usahakan kalau perlu sedikit lebih keras pada diri untuk tidak mengalami defisit karena defisit adalah sumber semua masalah besar yang mungkin muncul di masa mendatang. Prioritaskan pembayaran cicilan utang, lalu premi asuransi, kemudian biaya hidup. Pelajari cara mengeluarkan uang secara bijak untuk setiap pos pengeluaran. Ketiga, hati-hati dengan utang. Penjelasannya adalah caranya ketahui kapan sebaiknya berutang dan kapan tidak berutang. Kuasai tip yang diperlukan jika ingin mengambil utang atau membeli barang secara kredit. Kuasai tip yang diperlukan bila pada saat ini terlanjur memiliki utang .

Karvof (2010) menyatakan bahwa keputusan keuangan pribadi meliputi: Amal, sebesar $10 \%$ dari total pendapatan, pendidikan dan proteksi, sebesar $20 \%$ dari total pendapatan, investasi, sebesar $30 \%$ dari total pendapatan, biaya hidup. sebesar $40 \%$ dari total pendapatan. Nalarnya yaitu amal sebesar $10 \%$ merupakan bentuk dari tanggung jawab sosial individu (personal social responsibility) kepada sesama manusia, sehingga dengan literasi keuangan yang baikmaka seseorang juga diwajibkan untuk memberdayakan orang lain (philanthropy) untuk mencapai kebebasan keuangan (financial freedom). Maksud dari kebebasan keuangan adalah kondisi dimana pendapatan pasif melebihi pendapatan aktif atau melebihi pengeluaran pada suatu periode waktu tertentu, sedangkan pendapatan pasif diartikan sebagai pendapatan yang diterima walaupun orang tersebut tidak bekerja atau beraktifitas .

\section{Pengetahuan keuangan}

Tyfani dan Fitri (2019), Pengetahuan mengacu pada apa yang diketahui individu tentang masalah keuangan pribadi, yang diukur dengan tingkat pengetahuan mereka 
tentang berbagai konsep keuangan pribadi (Marsh, 2006). Financial knowledge adalah penguasaan seseorang atas berbagai hal tentang dunia keuangan (Kholilah dan Iramani, 2013) Pemuda belajar tentang uang sebagian besar dari sekolah dan orang tua, dengan penekanan pada penghematan (Chowa et.al, 2012). Pada perkembangannya, pengetahuan mengenai keuangan mulai diperkenalkan di berbagai jenjang pendidikan. Terdapat berbagai sumber pengetahuan yang dapat diperoleh, termasuk pendidikan formal, seperti program sekolah tinggi atau kuliah, seminar dan kelas pelatihan di luar sekolah, serta sumber-sumber informal, seperti dari orang tua, teman, dan lingkungan pekerjaan (Ida dan Dwinta, 2010) .

Pengetahuan keuangan (Personal financial literacy) didefenisikan sebagai pengetahuan mengenai konsep-konsep keuangan (Lusardi, 2008) dalam Maghfiroh (2017). Personal financial literacy mencakup pengetahuan dasar mengenai keuangan pribadi ( basic personal finance), pengetahuan mengenai manajemen uang (cash management), pengetahuan mengenai kredit dan utang, pengetahuan mengenai tabungan dan investasi serta pengetahuan mengenai risiko. Pemahaman tentang masalah keuangan pribadi lebih dalam lagi, diperlukan pengetahuan keuangan. Literasi keuangan dapat diartikan sebagai pengetahuan keuangan, yang memiliki tujuan untuk mencapai kesejahteraan (Lusardi \& Mitchell 2007) dalam Maghfiroh (2017). Hal tersebut perlu digaris bawahi sebagai persiapan kita nantinya saat globalisasi menyerang. Lebih spesifik lagi dijelaskan, globalisasi dalam bidang keuangan. Hilgert, Holgart, dan Baverly (2003) serta Cude, Lawrence, Lyons, Metzger, LeJeune, Marks, dan Machtmes (2006) dalam Maghfiroh ( 2017), juga menyatakan bahwa diperlukan pengetahuan tentang bagaimana mengelola keuangan serta bagaimana teknik berinvestasi yang nantinya bisa jadi hal yang tidak dapat diabaikan lagi seperti waktuwaktu seperti sebelum-sebelumnya. Maghfiroh (2017), alat keuangan (financial tools) merupakan bentuk dan bagian yang digunakan dalam memutuskan manajemen keuangan pribadi contohnya seperti cek, kartu kredit, kartu debit, dan uang tunai .

\section{Love of Money}

Menurut Tang (2008) dalam Maghfiroh (2017), pengertian love of money adalah sebagai perilaku seseorang terhadap uang, pengertian seseorang terhadap uang, serta keinginan dan aspirasi seseorang terhadap uang. Di negara Amerika Serikat, kesuksesan seseorang diukur dengan uang dan pendapatan yang diperolehnya (Rubenstein,1981 dalam Elias, 2010). Pada dunia bisnis, manajer menggunakan uang untuk menarik, mempertahankan, dan memotivasi karyawannya (Milkovich dan Newman, 2002 dalam Elias, 2010). Love of money juga dapat diartikan sebagai tingkat kecintaan seseorang terhadap uang, bagaimana seseorang menganggap pentingnya uang bagi kehidupan mereka. Uang adalah salah satu aspek yang sangat penting dalam kehidupan sehari-hari. Tang dan Chiu (2003) dalam Maghfirah (2017) berteori bahwa love of money sangat terkait dengan konsep ketamakan, Mereka menemukan bahwa karyawan Hong Kong dengan tingkat love of money yang lebih tinggi kurang puas dengan pekerjaan mereka dibandingkan dengan rekan-rekan mereka. Bahkan, Tang dan Chiu (2003) juga menemukan hubungan yang langsung antara love of money dan perilaku tidak etis di antara karyawan Hong Kong. Sehingga dengan cintanya seseorang terhadap uang dapat mengakibatkan seseorang lupa diri dengan nilai nilai etika dan moral yang dimilikinya. Yang pada akhirnya menghalalkan segala cara untuk memperoleh uang sebanyak-banyaknya .

Adapun faktor-faktor lain yang dapat mempengaruhi tingkat kecintaan seseorang terhadap uang. Empat faktor kecintaan terhadap uang pada penelitian ini mengacu pada Tang dan Chiu (2003) dalam Maghfirah (2017) yaitu: faktor kekayaan, motivator, sukses dan arti penting .

1. Faktor kekayaan, merefleksikan keinginan sebagian besar orang untuk kaya dan memiliki banyak uang. Faktor kaya merupakan komponen dari sikap yang berkenan dengan hubungan cinta dan benci seseorang pada objek. 
2. Faktor motivator (sebuah komponen perilaku) berkenaan dengan gagasan bahwa uang merupakan motivator.

3. Faktor kesuksesan (komponen kognitif) mewakili obsesi dengan uang sebagai tanda sukses individu.

4. Faktor arti penting (komponen kognitif menekankan "penting"nya uang dalam hidup.

\section{Kesejahteraan Masyarakat}

Chaniago (2012) dalam Devani Ariestha Sari ( 2016) mengatakan bahwa pembangunan belum bisa dikatakan berhasil bila salah satu atau dua dari tiga kondisi yaitu kemiskinan, pengangguran, dan ketimpangan masyarakat menjadi lebih buruk meskipun pendapatan perkapita melambung tinggi. Bank Dunia di bawah kepemimpinan Robert S Mc Namara tidak lagi hanya memberi perhatian pada mobilisasi dan penggunaan dana untuk meningkatkan kapasitas produksi negara-negara berkembang, tetapi juga menekankan pada tujuan-tujuan sosial, seperti memberantas kemiskinan dan mengurangi kesenjangan. Artinya, pembangunan yang dilakukan tidak saja semata-mata untuk kemajuan ekonomi namun juga untuk meningkatkan kesejahteraan sosial. Secara definitif, kesejahteraan sosial merupakan suatu kondisi atau keadaan sejahtera, baik fisik, mental maupun sosial, dan tidak hanya perbaikan terhadap penyakit sosial tertentu saja (Chalid, 2014) .

Undang-undang Nomor 11 tahun 2009 tentang Kesejahteraan Sosial menyebutkan kesejahteraan sosial adalah kondisi terpenuhinya kebutuhan material, spiritual, dan sosial warga negara agar dapat hidup layak dan mampu mengembangkan diri, sehingga dapat melaksanakan fungsi sosialnya. Menurut Suharto (2006), kesejahteraan social sedikitnya mengandung empat makna .

1. Kesejahteraan sosial sebagai kondisi sejahtera (well-being). Pengertian ini biasanya menunjuk pada istilah kesejahteraan sosial (social welfare) sebagai kondisi terpenuhinya kebutuhan materi dan nonmaterial. Midglye mendefinisikan kesejahteraan sosial sebagai a condition or state of human well-being. Kondisi sejahtera terjadi apabila kehidupan manusia aman dan bahagia karena kebutuhan dasar akan gizi, kesehatan, pendidikan, tempat tinggal dan pendapatan dapat dipenuhi, serta manakala manusia memperoleh perlindungan dari risiko-risiko utama yang mengancam kehidupannya.

2. Kesejahteraan sosial sebagai pelayanan sosial. Pelayanan sosial umumnya mencakup lima bentuk, yakni jaminan sosial (sosial security), pelayanan kesehatan, pendidikan, perumahan dan pelayanan sosial personal (personal social services).

3. Kesejahteraan sosial sebagai tunjangan sosial, khususnya diberikan kepada orang miskin.

4. Kesejahteraan sosial sebagai proses atau usaha terencana yang dilakukan oleh perorangan, lembaga-lembaga sosial, masyarakat maupun badan-badan pemerintah untuk meningkatkan kualitas kehidupan dan menyelenggarakan pelayanan social.

Taslim (2004) dalam Devani Ariestha Sari ( 2016) mengatakan dalam memahami realitas tingkat kesejahteraan, pada dasarnya terdapat beberapa faktor yang menyebabkan terjadinya kesenjangan tingkat kesejahteraan, antara lain sosial ekonomi rumah tangga atau masyarakat, struktur kegiatan ekonomi sektoral yang menjadi dasar kegiatan produksi rumah tangga atau masyarakat, potensial regional (sumber daya alam, lingkungan, dan infrastruktur) yang mempengaruhi perkembangan struktur kegiatan produksi, dan kondisi kelembagaan yang membentuk jaringan kerja produksi dan pemasaran pada skala lokal, regional, dan global

\section{Indikator Kesejahteraan Sosial}

Indikator yang digunakan oleh para ilmuwan sosial untuk mengukur kondisi kesejahteraan sosial cukup beragam. Untuk melihat sejauh mana keberhasilan pembangunan dan kesejahteraan manusia, UNDP telah menerbitkan suatu indikator yaitu 
Indeks Pembangunan Manusia (IPM) untuk mengukur kesuksesan pembangunan dan kesejahteraan suatu negara. IPM adalah suatu tolak ukur angka kesejahteraan suatu daerah atau negara yang dilihat berdasarkan tiga dimensi yaitu: angka harapan hidup pada waktu lahir (life expectancy at birth), angka melek huruf (literacy rate) dan rata-rata lama sekolah (mean years of schooling), dan kemampuan daya beli (purchasing power parity). Indikator angka harapan hidup mengukur kesehatan, indikator angka melek huruf penduduk dewasa dan rata-rata lama sekolah mengukur pendidikan dan terakhir indikator daya beli mengukur standar hidup. Sedangkan dalam Peraturan Pemerintah Nomor 8 Tahun 2008 tentang Tahapan, Tatacara Penyusunan, Pengendalian, dan Evaluasi Pelaksanaan Rencana Pembangunan Daerah, indikator yang digunakan untuk mengukur kesejahteraan dan pemerataan ekonomi adalah laju pertumbuhan ekonomi, laju inflasi provinsi, Pendapatan Regional Demestik Brutto (PDRB) per kapita, indeks gini, pemerataan pendapatan versi Bank Dunia, persentase penduduk di bawah garis kemiskinan dan angka kriminalitas yang tertangani. BPS mengukur kesejahteran rakyat melalui delapan bidang, yaitu kependudukan, kesehatan dan gizi, pendidikan, ketenagakerjaan, taraf dan pola konsumsi, perumahan dan lingkungan, kemiskinan, dan sosial lainnya .

Berdasarkan Undang-undang Nomor 11 tahun 2009 tentang Kesejahteraan Sosial menyebutkan kesejahteraan sosial adalah kondisi terpenuhinya kebutuhan material, spiritual, dan sosial. Salah satu indikator untuk menilai aspek spiritual adalah menggunakan indeks kebahagiaan. Indeks kebahagiaan ini merupakan komposit dari berbagai indikator subyektif. Menurut BPS, indikator kebahagiaan meliputi pekerjaan, pendapatan rumah tangga, kondisi rumah dan aset, pendidikan, kesehatan, keharmonisan keluarga, hubungan sosial, ketersediaan waktu luang, kondisi lingkungan, dan kondisi keamanan. Konsep kesejahteraan menurut Nasikun (1993) dapat dirumuskan sebagai padanan makna dari konsep martabat manusia yang dapat dilihat dari empat indikator yaitu : rasa aman (security), kesejahteraan (welfare), kebebasan (freedom), dan jati diri (identity). Badan Pusat Statistik Indonesia (2000) menerangkan bahwa guna melihat tingkat kesejahteraan rumah tangga suatu wilayah ada beberapa indicator yang dapat dijadikan ukuran, antara lain tingkat pendapatan keluarga, komposisi pengeluaran rumah tangga dengan membandingkan pengeluaran untuk pangan dan non-pangan, tingkat pendidikan keluarga, tingkat kesehatan keluarga, dan kondisi perumahan serta fasilitas yang dimiliki dalam rumah tangga .

\section{METODOLOGI PENELITIAN}

Metode dalam penelitian ini digunakan adalah Confirmatory Analysis Factor dengan pendekatan kuantitatif. Diuji menggunakan uji regression weight melalui software Amos SPSS 23. Reponden dalam penelitian ini adalah masyarakat Desa Cihambulu Kecamatan Pabuaran Kabupaten Subang Jawa Barat sebanyak 100 orang

Objek penelitian yaitu dengan melihat kodisi objek secara objektif, Peneliti menetapkan variabel operasional disusun sehingga memudahkan dalam mengumpulkan dan menjaring data yang didapat dari responden sesuai dengan teori yang di dapat, konsep proposisi dan asumsi-asumsi dari variabel penelitian yang dibuat. Adapun variabel operasional penelitian disajikan pada 


\section{Tabel 1.}

Variabel Operasional Penelitian

\begin{tabular}{|c|c|c|c|c|}
\hline \multirow{4}{*}{\begin{tabular}{l}
\multicolumn{1}{c}{ Variabel } \\
Variabel X \\
Pengetahuan \\
Keuangan \\
Dan Love Of \\
Money
\end{tabular}} & \multirow{6}{*}{\begin{tabular}{l}
\multicolumn{1}{c}{ Dimensi } \\
Pendapatan \\
Bunga dari Uang \\
(Compound \\
Interest)(X1)
\end{tabular}} & \multicolumn{2}{|r|}{ Indikator } & \multirow{6}{*}{$\begin{array}{l}\text { Skala } \\
\text { Skala } \\
\text { Likert }\end{array}$} \\
\hline & & PK1 & Menyimpan uang di bank & \\
\hline & & PK2 & $\begin{array}{l}\text { Tujuan mendeposito uang di } \\
\text { bank }\end{array}$ & \\
\hline & & PK3 & $\begin{array}{l}\text { Mendapatkan bunga lebih } \\
\text { banyak }\end{array}$ & \\
\hline & & PK4 & $\begin{array}{l}\text { Inflasi tingginya } \\
\text { konsumsi masyarakat yang } \\
\text { terus menerus }\end{array}$ & \\
\hline & & PK5 & Pemicu inflasi & \\
\hline & Nilai Waktu dari & PK6 & Uang di simpan bank & Skala \\
\hline & $\begin{array}{l}\text { Uang ( Time } \\
\text { Value Of Money) }\end{array}$ & PK7 & $\begin{array}{l}\text { Harga barang sekarang } \\
\text { akan datang }\end{array}$ & Likert \\
\hline & & PK8 & Perubahan Nilai mata uang & \\
\hline & & PK9 & Harga suatu barang & \\
\hline & $\begin{array}{l}\text { Diversifikasi } \\
\text { (Diversification) }\end{array}$ & PK10 & $\begin{array}{c}\text { Membeli saham } \\
\text { sendiri }\end{array}$ & $\begin{array}{l}\text { Skala } \\
\text { Likert }\end{array}$ \\
\hline & & PK11 & Membeli obligasi & \\
\hline & & PK12 & Berinvestasi pada saham & \\
\hline & & PK13 & Mendepositokan uang & \\
\hline Variabel Y & Penghematan/SVG & PK14 & Menabung sebagian dari gaji & Skala \\
\hline Pengelolaan & (Saving) & PK15 & Menyisihkan Keuangan & Likert \\
\hline keuangan & $(\mathrm{Y} 1)$ & PK16 & Membeli aset produktif & \\
\hline pribadi & Pengeluaran/EXP & PK17 & Merencanakan pengeluaran & Skala \\
\hline (Personal & (Expenditure) & PK18 & Membuat Budget Pengeluaran & Likert \\
\hline finance & (Y2) & PK19 & Pengeluaran Berlebihan & \\
\hline management) & Debt/DBT(Kelola & PK20 & Membayar tagihan tepat waktu & Skala \\
\hline & $\begin{array}{l}\text { Utang) } \\
\text { (Y3) }\end{array}$ & PK21 & $\begin{array}{l}\text { Membuat perencanaan } \\
\text { pembayaran utang }\end{array}$ & Likert \\
\hline & & PK22 & Tidak Berutang & \\
\hline & Mengelola Uang / & PK23 & Mengalami masalah keuangan & Skala \\
\hline & $\begin{array}{l}\text { MNG (Money } \\
\text { management) }\end{array}$ & PK24 & $\begin{array}{l}\text { Mempunyai tujuan Pengelolaan } \\
\text { uang }\end{array}$ & Likert \\
\hline & $(\mathrm{Y} 4)$ & PK25 & Pencapaian tujuan pengelolaan & \\
\hline & Dana Pensiun/RTM & PK26 & Menyiapkan dana untuk pensiun & Skala \\
\hline & $\begin{array}{l}\text { (Retirement) } \\
\text { (Y5) }\end{array}$ & PK27 & $\begin{array}{l}\text { Menyiapkan dana Pendidikan } \\
\text { untuk pension }\end{array}$ & Likert \\
\hline & & PK28 & $\begin{array}{l}\text { Menyiapkan dana Asuransi } \\
\text { kesehatan untuk pensiun }\end{array}$ & \\
\hline & & PK29 & $\begin{array}{l}\text { Menyiapkan dana investasi untuk } \\
\text { pension }\end{array}$ & \\
\hline Variabel Z & KMD (Z) & PK30 & Identifikasi masalah (IDM) & Skala \\
\hline $\begin{array}{l}\text { Kesejahteraan } \\
\text { Masyarakat }\end{array}$ & & PK31 & $\begin{array}{l}\text { Pengumpulan informasi yang } \\
\text { relevan (PIR) }\end{array}$ & Likert \\
\hline
\end{tabular}

Jurnal SEKURITAS(Saham, Ekonomi, Keuangan dan Investasi ) , Vol.4, No.1, September 2020... 50 


\begin{tabular}{|l|l|l|l|}
\hline Desa & PK32 & Alternatif tindakan (ALT) \\
\cline { 3 - 4 } & PK33 & Analisis alternative ANL) \\
\cline { 3 - 4 } & PK34 & Memilih alternatif terbaik (MAT) \\
\cline { 3 - 4 } & PK35 & $\begin{array}{l}\text { Melaksakan keputusan dan } \\
\text { alternatif evaluasi (EVA) }\end{array}$ \\
\hline
\end{tabular}

Sumber : (olahan 2020)

\section{Kerangka Berpikir Penelitian}

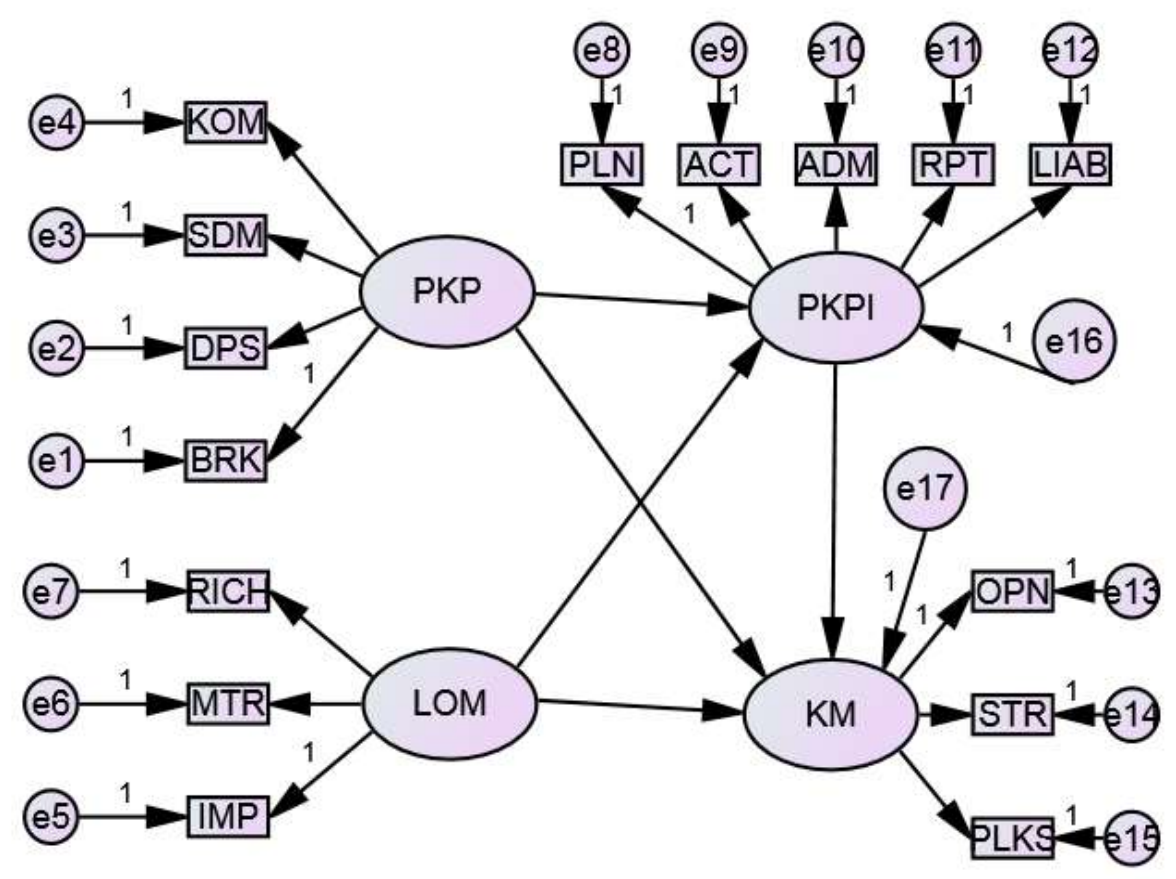

Gambar 1. Kerangka Berpikir

Berdasarkan kerangka ajuan diatas maka hipotesis yang diangkat sebagai berikut:

$\mathrm{H} 1$ : Pengetahuan Keuangan Pribadi berpengaruh terhadap Pengelolaan Keuangan Pribadi

H2 : Love Of Money berpengaruh Terhadap Pengelolaan Keuangan Pribadi.

H3 : Pengetahuan Keuangan Pribadi (personal finance management) berengaruh terhadap Kesejahteraan Masyarakat Desa.

H4 ; Love Of Money Berpengaruh Terhadap Kesejahteraan Masyaraat Desa

H5 ; Pengelolaan Keuangan Pribadi Berpengaruh Terhadap Kesejahteraan Masyarakat Desa

Berdasarkan isi pokok penelitian yang dilakukan, sasaran populasi dari penelitian ini adalah masyarakat dan aparatur desa yang telah Responden penelitian adalah adalah mahasiswa program pascasarjana magister manajemen S2 Universitas Pamulang. 


\section{HASIL DAN PEMBAHASAN}

Lokasi penelitian di Desa Cihambulu Kecamatan Pabuaran Kabupaten Subang

\section{Uji Instrumen Penelitian}

Uji-Validitas Data

\section{Tabel 2 ; Hasil Uji-Validitas Var. X, Y dan Z}

\begin{tabular}{|c|c|c|c|c|}
\hline Variabel & Indikator & $\begin{array}{c}\mathbf{R} \\
\text { Hitung }\end{array}$ & R Tabel & $\begin{array}{r}\text { Kriteria } \\
\text { Validitas }\end{array}$ \\
\hline \multirow{8}{*}{$\begin{array}{l}\text { Variabel X } \\
\text { Pengetahuan Keuangan } \\
\text { Dan Love Of Money }\end{array}$} & BRK (X1) & 0,464 & 0,198 & Valid \\
\hline & DPS (X2) & 0,629 & 0,198 & Valid \\
\hline & SDM (X3) & 0,462 & 0,198 & Valid \\
\hline & KOM (X4) & 0,571 & 0,198 & Valid \\
\hline & IMP (X5) & 0,552 & 0,198 & Valid \\
\hline & MTR $(X 6)$ & 0,647 & 0,198 & Valid \\
\hline & $\mathrm{RICH}(\mathrm{X} 7)$ & 0,638 & 0,198 & Valid \\
\hline & BRKX10 & 1,000 & 0,198 & Valid \\
\hline
\end{tabular}

\begin{tabular}{|l|l|l|l|l|}
\hline \multicolumn{1}{|c|}{ Variabel } & \multicolumn{1}{|c|}{ Indikator } & Hitung & R Tabel & \multicolumn{1}{c|}{$\begin{array}{c}\text { Kriteria } \\
\text { Validitas }\end{array}$} \\
\hline \multirow{2}{*}{$\begin{array}{l}\text { Variabel } Y \\
\text { Pengelolaan Keuangan }\end{array}$} & PLN (Y1) & 0,455 & 0,198 & Valid \\
\cline { 2 - 5 } & ACT (Y2) & 0,637 & 0,198 & Valid \\
\cline { 2 - 5 } & ADM (Y3) & 0,327 & 0,198 & Valid \\
\cline { 2 - 5 } & RPT (Y4) & 0,395 & 0,198 & Valid \\
\cline { 2 - 5 } & LIAB (Y5) & 0,468 & 0,198 & Valid \\
\hline
\end{tabular}

\begin{tabular}{|l|l|c|c|c|}
\hline \multicolumn{1}{|c|}{ Variabel } & \multicolumn{1}{c|}{$\begin{array}{c}\mathbf{R} \\
\text { Indikator }\end{array}$} & Hitung & R Tabel & \multicolumn{1}{c|}{$\begin{array}{c}\text { Kriteria } \\
\text { Validitas }\end{array}$} \\
\hline \multirow{2}{*}{$\begin{array}{l}\text { Variabel Z } \\
\text { Kesejahteraan Masyarakat }\end{array}$} & OPN (Z1) & 0,524 & 0,198 & Valid \\
\cline { 2 - 5 } & STR (Z4) & 0,461 & 0,198 & Valid \\
\cline { 2 - 5 } & PLKS (Z5) & 0,622 & 0,198 & Valid \\
\hline
\end{tabular}

Sumber: Output SPSS 23

Data tabel diatas menunjukkan bahwa semua indikator penelitian dikatagorikan nilainya valid dengan nilai R-hitung lebih besar (>)dari nilai R-Tabel maka Analisa berikutnya dapat dilanjutkan.

\section{Uji-Reliabilitas}

\section{Tabel 4 ;Uji-Reliabilitas}

\begin{tabular}{|l|c|c|}
\hline \multicolumn{1}{|c|}{ Variabel latent } & $\begin{array}{c}\text { Koefisien Raliabilitias } \\
\text { Cronbach's Alpha }\end{array}$ & Kreteria Uji \\
\hline Pengetahuan dan Love Of Money & 0,921 & Realiabel \\
\hline Pengelolaan Keuangan Pribadi & 0.897 & Realiabel \\
\hline
\end{tabular}




\section{Kesejahteraan Masyrakat Desa}

0,944

Realiabel

Sumber: Output SPSS 23

Dari table diatas dapat dilihat nilai alpha cronbach kepuasan wisatawan 0,920 0,60 dan loyalitas wisatawan 0,905 > 0,60 kedua variabel berdasarkan kriteria uji , dikatakan reliabel

\section{Uji-Goodness -offit Indices}

Tabel 5 ; Evaluasi Kriteria Goodness-offit Indices

\begin{tabular}{|l|c|c|c|}
\hline \multicolumn{1}{|c|}{ Kreteria } & $\begin{array}{c}\text { Hasil } \\
\text { Model }\end{array}$ & Nilai Kritis & Evaluasi Model \\
\hline Chi-Square $X^{2}$ CMIN & 91.596 & $\begin{array}{c}\text { Besar, } X^{2} \\
\text { dengan } \mathrm{df}=1 \\
\text { adalah } 0,997\end{array}$ & Baik \\
\hline Probability (P) & 0.036 & $\geq 0.05$ & Kurang Baik \\
\hline$X^{2}$ Relatif (CMIN/DF) & 1.327 & $\leq 2.0$ & Baik \\
\hline GFI & 0.897 & $\geq 0.90$ & Baik \\
\hline AGF & 0.821 & $\geq 0.90$ & Kurang Baik \\
\hline TLI & 0.974 & $\geq 0.95$ & Baik \\
\hline CFI & 0.983 & $\geq 0.95$ & Baik \\
\hline RMSEA & 0.058 & $\leq 0.08$ & Baik \\
\hline
\end{tabular}

Sumber : Pengolahan data Amos SPSS

Confirmatory Factor Analysis pada measurement model dalam penelitian ini menunjukan model yang baik, dimana nilai GFI sama dengan tingkat yang disarankan 0.90; Sebagian besar hasil pengujian dengan kriteria yang baik

\section{Hasil Uji-Regression Weight}

Tabel 6 Regression Weight (Loading Factor) Measurement Model Maximum Likelihood Estimates)

Regression Weights: (Group number 1 - Default model)

\begin{tabular}{|c|c|c|c|c|c|c|c|}
\hline & & & Estimate & S.E. & C.R. & $P$ & Label \\
\hline PKPI & <--- & PKP & ,007 & ,427 & ,016 & ,987 & par_12 \\
\hline PKPI & $<--$ & LOM & ,460 & ,240 & 1,915 & ,056 & par 14 \\
\hline KM & $<--$ & PKP &,- 216 & 281 &,- 769 & ,442 & par_13 \\
\hline KM & $<--$ & PKPI & 1,974 & 263 & 7,516 & $* * *$ & par_15 \\
\hline KM & $<--$ & LOM & ,093 & , 156 &, 596 & ,551 & par_16 \\
\hline BRK & $<---$ & PKP & 1,000 & & & & \\
\hline DPS & $<--$ & PKP & ,765 & ,099 & 7,738 & $* * *$ & par_1 \\
\hline SDM & $<--$ & PKP & 1,682 & 151 & 11,149 & $* * *$ & par_2 \\
\hline KOM & $<--$ & PKP & 1,374 & 154 & 8,940 & $* * *$ & par_3 \\
\hline IMP & $<---$ & LOM & 1,000 & & & & \\
\hline MTR & $<--$ & LOM & ,286 & ,066 & 4,317 & $* * *$ & par 4 \\
\hline $\mathrm{RICH}$ & $<--$ & LOM & 283 & ,067 & 4,236 & $* * *$ & par_5 \\
\hline PLN & $<--$ & PKPI & 1,000 & & & & \\
\hline
\end{tabular}




\begin{tabular}{|c|c|c|c|c|c|c|c|}
\hline & & & Estimate & S.E. & C.R. & $P$ & Label \\
\hline ACT & $<-$ & PKPI & 1,171 &, 111 & 10,570 & $* * *$ & par_6 \\
\hline ADM & $<--$ & PKPI & 1,055 & ,094 & 11,226 & *** & par_7 \\
\hline RPT & $<-$ & PKPI & 1,285 & 145 & 8,836 & *** & par_8 \\
\hline LIAB & $<-$ & PKPI & 1,187 & 119 & 10,010 & *** & par_9 \\
\hline OPN & $<--$ & $\mathrm{KM}$ & 1,000 & & & & \\
\hline STR & $<--$ & KM & ,978 & ,073 & 13,333 & *** & par_10 \\
\hline PLKS & $<--$ & $\mathrm{KM}$ & ,701 & ,068 & 10,366 & $* * *$ & par_11 \\
\hline
\end{tabular}

Sumber : Pengolahan dengan Amos SPSS

Tabel diatas menunjukan hasil regresi yang diperoleh melalui hasil perhitungan dengan menggunakan Amos SPSS 23, dari hasil regersi diperoleh hampir semua pengaruh memiliki nilai $P$ lebih kecil $\leq 0,05$ dan Critical Ratio $(C . R) \geq 1,96$ artinya mendukung hipotesis.

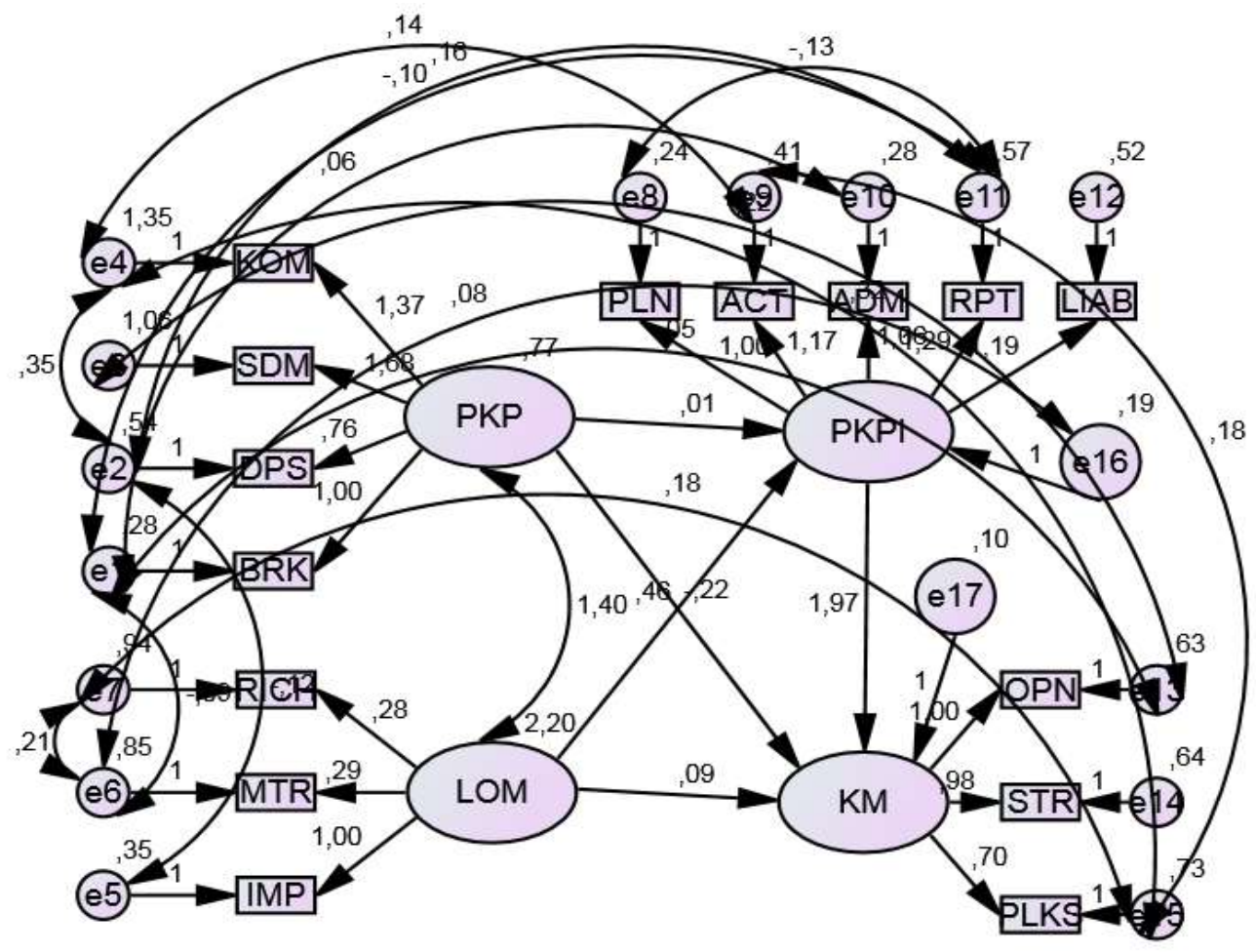

Uji Hipotesis

Chi-Square $=91,596$
Probability $=, 036$
CMIN/DF $=1,327$
GFI $=, 897$
AGFI $=, 821$
TLI $=, 974$
CFI $=, 983$
RMSEA $=, 058$

Gambar2 Hasil Pengolahan Data Amos SPSS 23 
Maka dapat disimpulan sbb:

1. Pengetahuan Keuangan Pribadi (PKP) tidak berpengaruh secara signifikan terhadap Pengelolaan Keuangan Pribadi (PKPI) dengan nilai C.R. (Critical Rasio) $(0,016)$ lebih kecil dari 1,96 $(0.016<1,196)$.

2. Love Of Money (LOM) tidak berpengaruh secara signifikan terhadap Pengelolaan Keuangan Pribadi (PKPI) dimana Critical Rasio lebih kecil dari 1,96 $(1,914<1,96)$

3. Pengetahuan Keuangan Pribadi (PKP) tidak berpengaruh secara signifikan terhadap Kesejahteraan Masyarakat Desa (KM) dimana Critical Rasio lebih kecil dari 1,96 ($0,769<1,96)$.

4. Love Of Money (LOM) tidak berpengaruh secara signifikan terhadap Kesejahteraan Masyaraat Desa (KM) dimana Critical Rasio $(0,596)$ lebih kecil dari 1,96 (-0,596 < 1,96).

5. Pengelolaan Keuangan Pribadi Berpengaruh secara signifikan Terhadap Kesejahteraan Masyarakat Desa dimana Critical Rasio $(7,516)$ lebih besar dari 1,96. ( $7,516>1,96)$.

\section{E. KESIMPULAN}

\section{Kesimpulan}

Dengan metode confirmatory analys factor menggunakan uji regression weight melalui perangkat Amos SPSS 23 . Responden adalah warga desa Cihambulu sebanyak 100 orang. Hasil penelitian menunjukkan:

1. Pengetahuan Keuangan Pribadi (PKP) tidak berpengaruh secara signifikan terhadap Pengelolaan Keuangan Pribadi (PKPI).

2. Love Of Money (LOM) tidak berpengaruh secara signifikan terhadap Pengelolaan Keuangan Pribadi (PKPI).

3. Pengetahuan Keuangan Pribadi (PKP) tidak berpengaruh secara signifikan terhadap Kesejahteraan Masyarakat Desa (KM).

4. Love Of Money (LOM) tidak berpengaruh secara signifikan terhadap Kesejahteraan Masyaraat Desa (KM).

5. Pengelolaan Keuangan Pribadi Berpengaruh secara signifikan Terhadap Kesejahteraan Masyarakat Desa.

\section{Saran}

Berdasarkan rata - rata jawaban responden terhadap kuisioner terdapat beberapa item dengan nilai rata - rata paling rendah yaitu dari 100 responden menjawab rata - rata dengan skor 3,03 pada item Indikator Pelaksanaan, baik dalam perencanaan pelaksanaan program, strategi dan pengorganisasian program dan pengawasan terhadap pelaksaksanaan program dari unsur terkait. Atau secara keseluruhan proses manajemen dalam pelaksanaan masih kurang baik, diharapkan penelitian ini dapat menjadi masukan bagi aparat pemerintah desa Cihambulu, Pabuaran, Subang, Jawa Barat dalam hal memberikan pengetahuan dan pelatihan khususnya manajemen keuangan sehingga kedepan pemerintah desa dapat menjalankan proses aplikasinya ke masyarakat dengan baik, selain itu perlu adanya literasi dan edukasi mengenai pengetahuan dan pengelolaan Jurnal SEKURITAS(Saham, Ekonomi, Keuangan dan Investasi ) , Vol.4, No.1, September 2020... 55 
keuangan secara kontinnyu untuk masyarakat agar terwujud Kesejahteraan Masyarakat secara Mandiri.

\section{DAFTAR PUSTAKA}

Abdul Kadim, K., \& Nardi Sunardi, S. (2018). Determinant Of Company's Likuidity And It's Implications On Financial's Performance Of Ritail Trade Company's In Indonesia At The Period Of 2008-2017. Global and Stockhastic Analysis, 5(7), 235-247.

Guitman LJ, Z. C. (2012). "Principles of Managerial Financial Global Edition 13th Edition". England:: Person Education Limited 2012.

Gujarati Damodar N, F. D. (2013). "Basic Econometrics, 5th Edition. Diterjemahkan oleh: Eugenia Mardanugraha", Sita Mardani, Carlos Mangunsong. (2013). Dasar-dasar Ekonometrika. Jakarta:: Salemba Empat.

Hakim, L., Sunardi, N. (2017). Determinant of leverage and it's implication on company value of real estate and property sector listing in IDX period of 2011-2015. Man in India, 97(24), pp. 131-148

Houston, B. \&. (2013). "Essential of Financial Management. Original edition first published by Cengage Learning 2007,Diterjemahkan oleh: Ali Akbar Yulianto. 2011".

Kadim, A., Sunardi, N., \& Husain, T. (2020). The modeling firm's value based on financial ratios, intellectual capital and dividend policy. Accounting, 6(5), 859-870.

Lesmana, R., Sunardi, N., Hasbiyah, W., Tumanggor, M., \& Susanto, S. (2019). Manajemen Alokasi Dana Desa dalam Upaya dan Strategi Mewujudkan Desa Sejahtera Mandiri di Desa Cihambulu, Kec. Pabuaran, Kab. Subang, Jawa Barat. Jurnal Abdi Masyarakat Humanis, 1(1).

Nardi Sunardi, E. A., Kadim, A., Tumanggor, M., \& Oktrima, B. (2018). Effects Of The Bank Soundness With The Rbbr Approach (Risk Base Bank Rating) Of Cost Efficiency And Its Implications On Sharia Bank Performance In Indonesia For The Period Of 20122016. International Journal of Economic Research, 15(1).

.Peraturan Menteri Dalam Negeri Nomor 113 Tahun 2014 tentang Pengelolaan Keuangan Desa.

Peraturan Menteri Dalam Negeri nomor 114 tahun 2014 tentang Pedoman Pembangunan Desa.

Sarwani, S., Sunardi, N., AM, E. N., Marjohan, M., \& Hamsinah, H. (2020). Penerapan IImu Manajemen dalam Pengembangan Agroindustri Biogas dari Limbah Kotoran Sapi yang Berdampak pada Kesejahtraan Masyarakat Desa Sindanglaya Kec. Tanjungsiang, Kab. Subang. Jurnal Abdi Masyarakat Humanis, 1(2).

Sugiyono. (2013). Memahami Penelitian Kualitatif. Bandung: Alfabeta

Senduk. 2001. Manajemen Keuangan, konsep, dan aplikasi. Yogyakarta: Mediacom. 